Josefine Radke, MD

Debora Pehl, MD

Eleonora Aronica, MD,

$\mathrm{PhD}$

Dieneke Schonenberg-

Meinema, MD

Udo Schneider, MD

Frank L. Heppner, MD

Marianne de Visser, MD

Hans H. Goebel, MD

Werner Stenzel, MD

Correspondence to

Dr. Radke:

josefine.radke@charite.de

\section{Supplemental data} at Neurology.org/nn

\title{
The lymphoid follicle variant of dermatomyositis
}

\section{OPEN}

ABSTRACT

Objective: To investigate the clinical and morphologic spectrum of early adult-onset dermatomyositis (DM), an inflammatory disease that affects small vessels of the muscle and the skin.

Methods: Histologic evaluation of frozen muscle samples was employed to visualize the cellular organization of ectopic lymphoid structures in muscle biopsies obtained from 2 patients diagnosed with DM. Clinical presentation and morphologic features, as well as treatment and follow-up, were assessed and documented. Electron microscopy was used to confirm the light microscopic diagnosis of DM. Clonality analysis of B-cell populations using PCR was performed.

Results: Muscle biopsy of both patients fulfilled the morphologic European Neuromuscular Centre criteria of DM. Analyses of muscle biopsy samples revealed ectopic lymphoid follicle-like structures that showed a remarkable similarity to secondary lymphoid organs (SLOs) with distinct $\mathrm{T}$ - and B-cell compartmentalization. Our 2 patients exhibited an atypical and mild clinical presentation and responded favorably to therapy.

Conclusions: The clinical and histopathologic features of DM can be atypical, and the presence of SLOs is not inevitably linked to an unfavorable prognosis. Neurol Neuroimmunol Neuroinflammation 2014;1:e19; doi: 10.1212/NXI.0000000000000019

\section{GLOSSARY}

$\mathbf{C K}=$ creatine kinase; $\mathbf{C O X}=$ cytochrome c oxidase; $\mathbf{D M}=$ dermatomyositis; $\mathbf{G C}=$ germinal center; IIM = idiopathic inflammatory myopathy; IVIg = IV immunoglobulin; jDM = juvenile dermatomyositis; LFLS = lymphoid follicle-like structures; MAC = membrane attack complex; $\mathbf{M H C}=$ major histocompatibility complex; SLO = secondary lymphoid organ.

Dermatomyositis (DM) is considered a complement-mediated vasculopathy. ${ }^{1}$ Diagnostic criteria have been defined and include characteristic skin findings, subacute onset of proximal symmetrical muscle weakness, and histologically membrane attack complex (MAC) deposition on capillary walls, or reduced capillary density, or major histocompatibility complex (MHC) class I expression of perifascicular fibers associated with perivascular, perimysial inflammatory cell infiltrate consisting of macrophages and $\mathrm{CD}^{+}$lymphocytes as well as ultrastructurally undulating tubules in endothelial cells. ${ }^{1}$ Although regularly mentioned as being involved in pathogenicity of DM, the precise role of B lymphocytes is not fully understood and not used as an individual diagnostic criterion. Recently it has been suggested that the presence of ectopic lymphoid structures in juvenile DM (jDM) was associated with adverse disease outcome. ${ }^{2}$

METHODS Histologic, enzyme histochemical, and immunohistochemical studies. Histologic, immunohistochemical, and enzyme histochemical stains were performed on $9-\mu \mathrm{m}$ cryostat sections. Hematoxylin \& eosin and Gomori trichrome stains were prepared according to standard procedures. Immunohistochemistry and enzyme histochemical stains were performed as previously described. ${ }^{3}$ Primary antibodies used in this study are listed in table e- 1 at Neurology.org/nn. Omission of the primary antibody resulted in no staining.

From the Departments of Neuropathology (J.R., D.P., F.L.H., H.H.G., W.S.) and Rheumatology and Clinical Immunology (U.S.), Charité Universitätsmedizin Berlin, Germany; and Departments of (Neuro) Pathology (E.A.), Pediatric Hematology, Immunology, Rheumatology and Infectious Disease, Emma Children's Hospital (D.S.-M.), and Neurology and Neurophysiology (M.d.V.), Academic Medical Centre, University of Amsterdam, the Netherlands.

Go to Neurology.org/nn for full disclosures. Funding information and disclosures deemed relevant by the authors, if any, are provided at the end of the article. The Article Processing Charge was paid by Charité Universitätsmedizin Berlin.

This is an open access article distributed under the terms of the Creative Commons Attribution-Noncommercial No Derivative 3.0 License, which permits downloading and sharing the work provided it is properly cited. The work cannot be changed in any way or used commercially. 
Electron microscopy. Muscle specimens were also examined by electron microscopy, which was performed as described previously. ${ }^{4}$

B-cell clonality analysis. B-cell clonality was assessed in both patients' specimens by PCR amplification using a set of BIOMED2 assays (InVivoScribe Technologies, San Diego, CA). Loci for IGH [IGHA: FR1 (variable region framework 1)-J; IGHB: FR2-J; IGHC: FR3-J] and for IGL (V-J) were targeted. ${ }^{5}$

RESULTS Patient 1, a 27-year-old woman, had a 7 -year history of unilateral swelling of her left biceps muscle and hand as well as wrist pain and morning stiffness of her finger joints. A contrast-enhanced MRI of her left biceps showed diffuse gadolinium uptake, thickening of the muscle fascia, and muscle edema (figure 1). On neurologic examination she showed normal symmetrical muscle strength and normal fine motor skills. Thorough examination of the skin did not reveal any abnormalities. Laboratory examination of her blood serum showed elevated immunglobulin E, C-reactive protein, and antinuclear and anti-cyclic citrullinated peptide antibodies. Serum creatine kinase $(\mathrm{CK})$ was normal. There was no evidence of rheumatoid arthritis. Based on the international consensus criteria, ${ }^{1}$ biopsy of the left biceps gave a diagnosis of DM with accompanying B-cell-rich follicle-like structures. An initial highdose $(1 \mathrm{mg} / \mathrm{kg} / \mathrm{d})$ prednisolone treatment over 4 weeks followed by a low-dose treatment $(5 \mathrm{mg} / \mathrm{d})$ led to rapid improvement and persistent resolution of her symptoms over a 1-year period.

Patient 2, a 17-year-old girl, was referred because of a 5-month history of painful reddish swellings of the left upper arm followed by similar symptoms in her right upper arm. There were no alterations of the skin or muscle weakness. Three weeks prior to referral she had arthralgia of the hands, knees, and feet, and morning stiffness. On neurologic examination no additional abnormalities were found. She had a normal serum CK

Figure 1 Contrast-enhanced MRI of affected muscles in both patients
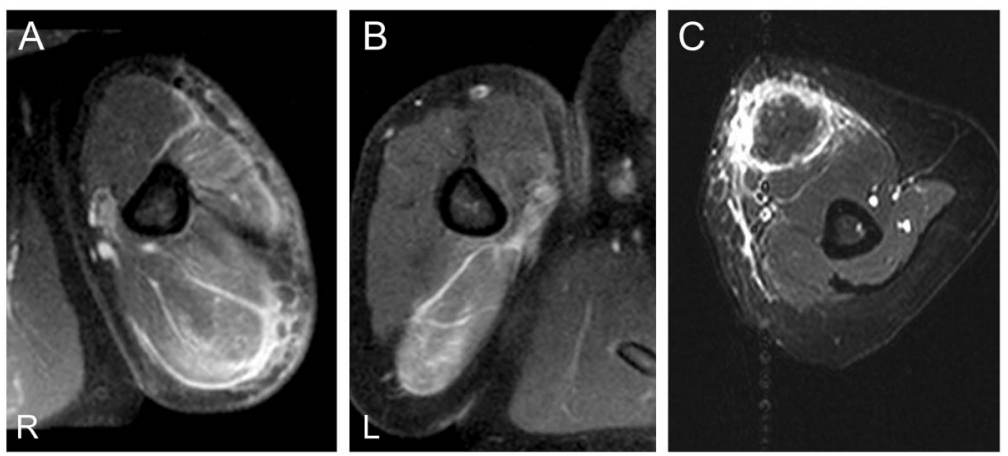

Contrast-enhanced MRI (T1) revealed areas of hyperintensity with diffuse gadolinium uptake in the affected muscle. Patient 1: left biceps (C); patient 2: right deltoid and left triceps brachii muscles (A, B). and erythrocyte sedimentation rate and a positive antinuclear antibody titer. MRI of the upper arms revealed hyperintensity in the right deltoid and left triceps muscles (figure 1, A and B). A biopsy of the left triceps showed a picture consistent with $\mathrm{DM}^{1}$ with accompanying B-cell-rich follicle-like structures. She was treated with methylprednisolone pulse therapy $(1,000 \mathrm{mg}$ for 3 consecutive days) and monthly IV immunoglobulin (IVIg) and subsequently received $60 \mathrm{mg}$ prednisone daily and methotrexate $(17.5 \mathrm{mg})$ weekly. Shortly after initiation of treatment she developed Gottron papules. Otherwise she responded favorably to therapy. Both IVIg and prednisone were successfully tapered, and currently she receives subcutaneous methotrexate and hydroxychloroquine, which has led to sustained improvement of her symptoms. Except for some minor alterations of the skin there remained no signs of active disease.

Muscle morphology. Muscle biopsies of both patients revealed extensive infiltration by inflammatory cells mainly in the perimysium and endomysium (figure 2, A-D). In addition, the infiltrates were located at perivascular sites. $\mathrm{CD}^{+} 8^{+}$macrophages (figure $2 \mathrm{~F}$ ) were diffusely distributed throughout the perimysium. MAC (C5b-9) deposition was mainly found on small capillaries and on the sarcolemma of single muscle fibers (figure 2G, arrowhead). MHC class II was expressed by the lymphoid cells and was found on numerous muscle fibers, predominantly in the perifascicular area (figure 2I). Sarcolemmal MHC class I expression was detected on all muscle fibers with perifascicular enhancement (figure 2J). Combined cytochrome c oxidase (COX)/succinate dehydrogenase histochemistry revealed scattered COX-negative fibers as a sign of accompanying mitochondrial dysfunction (figure $2 \mathrm{~K}$ ). $\mathrm{CD} 23^{+}$dendritic cells (figure 2L) and $\mathrm{CD}_{138^{+}}$plasma cells (figure 2M) were found in close proximity to $\mathrm{T}$ - and B-cell areas. The lymphoid follicle-like structures (LFLS) were mainly composed of $\mathrm{CD}^{+} 5^{+}$leukocytes (figure 2E) with $\mathrm{CD}^{+}$(figure $2 \mathrm{~N}$ ) and $\mathrm{CD}^{+}$(figure 2O) $\mathrm{T}$ cells distributed around $\mathrm{CD}^{+} 9^{+} \mathrm{B}$ cells (figure 2P). Expression patterns of peripheral $\mathrm{Bcl}-2$ (figure 2Q), central Bcl-6 (figure 2R), and BOB.1 (figure 2S) paralleled the specific lymphoid follicle-like B-cell pattern. The Ki67/Mib-1 proliferation index was increased within the center of the follicle-like structures (figure 2T).

Electron microscopy revealed undulating tubules in endothelial cells of both patients, which supported the light microscopic diagnosis of DM (figure $2 \mathrm{H}$, arrowheads).

To exclude the presence of a neoplastic B-cell population as described for B-cell lymphomas within skeletal 

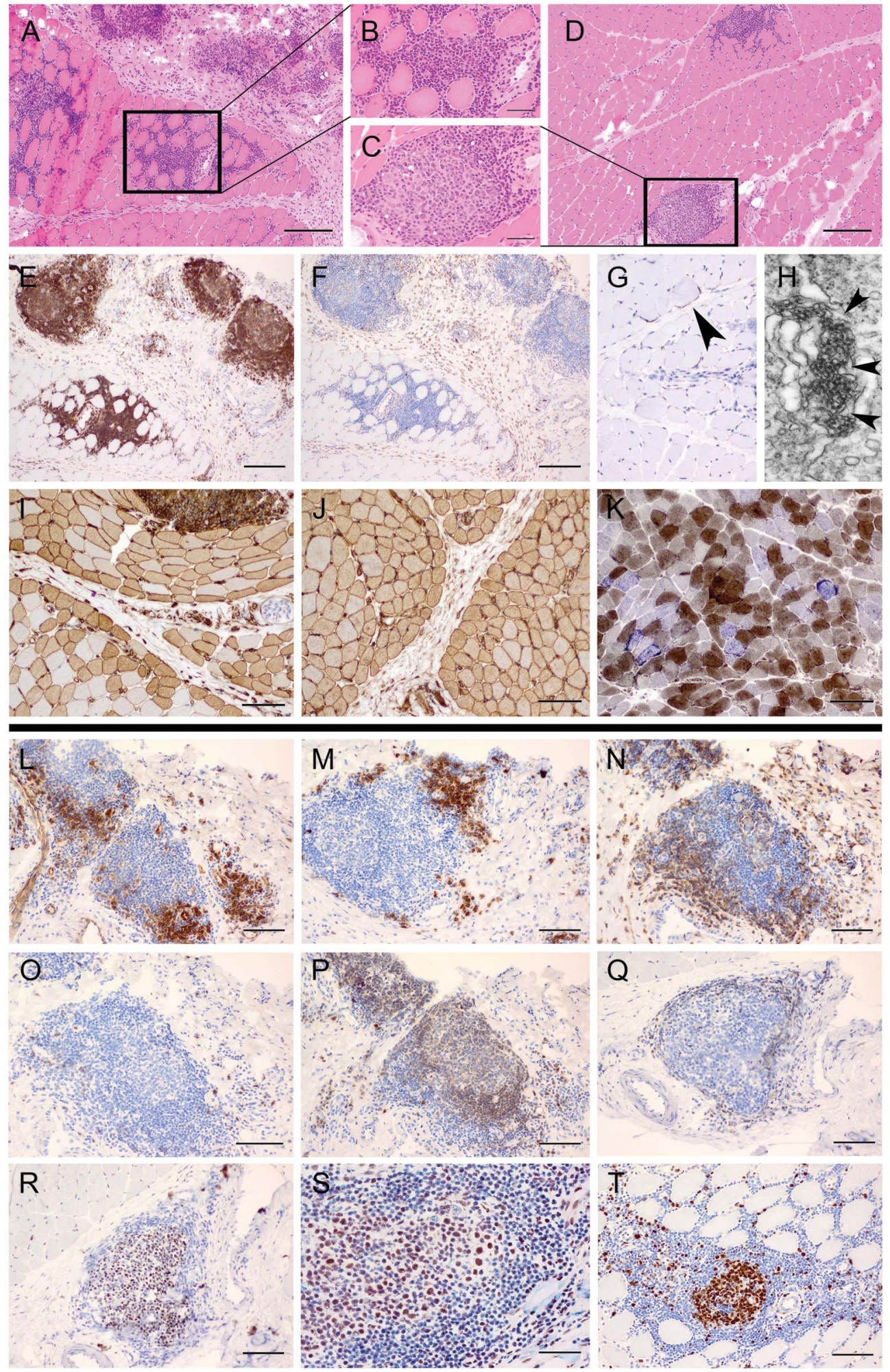

Serial sections of muscle biopsy stained with hematoxylin \& eosin revealed ectopic lymphoid follicle-like structures (patient 1: $A$ and $B$; patient 2: $C$ and D). Sections were stained with an antibody against $C D 45^{+}$leukocytes (E) to highlight the follicle-like inflammatory infiltrate. $\mathrm{CD}^{+} 8^{+}$macrophages (F) were diffusely distributed throughout the perimysium. C5b-9 was mainly found in walls of small capillaries and on the sarcolemma of single muscle fibers (G, arrowhead). Electron microscopy revealed ultrastructural evidence of undulating tubules (patient 1: $\mathrm{H}$, arrowheads, $50,000 \times$; patient 2: not shown). Major histocompatibility complex (MHC) class II was expressed by the lymphoid cells and was found on numerous muscle fibers, predominantly in the perifascicular area (I). Sarcolemmal MHC class I expression was detected on all muscle fibers (J). Combined cytochrome c oxidase (COX)/succinate dehydrogenase staining revealed blue-stained fibers indicating reduced COX activity (K). The lymphoid follicle-like structures consisted 
of $\mathrm{CD} 123^{+}$dendritic cells $(\mathrm{L}), \mathrm{CD} 138^{+}$plasma cells $(\mathrm{M})$, and $\mathrm{CD}^{+}(\mathrm{N})$ and $\mathrm{CD}^{+}(\mathrm{O}) \mathrm{T}$ cells that were distributed around $\mathrm{CD} 79 \mathrm{a}^{+}$ (P) B cells. Expression patterns of Bcl-2 (Q), Bcl-6 (R), and BOB.1 (S) illustrate lymphoid follicle-like structures with increased proliferative activity in the B-cell areas as indicated by Ki67/Mib-1 immunostaining (T). Scale bars: A, D, E, F, K: 200 ㅆm; B, C, G, S: $50 \mu \mathrm{m} ; \mathrm{I}, \mathrm{J}, \mathrm{L}-\mathrm{R}, \mathrm{T}: 100 \mu \mathrm{m}$.

muscle, ${ }^{6}$ we performed a B-cell clonality analysis. A monoclonal B-cell population was not detected.

DISCUSSION We present 2 patients diagnosed with DM with unusual clinical features. Since both patients initially presented with unilateral muscle swellings, no detectable muscle weakness, and lack of CK elevation, the diagnostic criteria of DM, according to the European Neuromuscular Centre, ${ }^{1}$ and jDM, according to the international consensus criteria, ${ }^{7}$ were not present. However, the morphologic criteria to diagnose $\mathrm{DM}^{1}$ were perfectly fulfilled, including the presence of undulating tubules known to be detectable in early-stage DM, ${ }^{4}$ emphasizing the need for muscle biopsy in these patients. Muscle biopsy of both patients also showed characteristic LFLS with defined T- and B-cell compartmentalization, which is a very rare finding in a very small subset of patients with jDM² and "overlap syndrome." ${ }^{\text {E Ectopic }}$ lymphoid follicles are a well-known histopathologic feature in other autoimmune diseases, including multiple sclerosis with meningeal inflammation, Sjögren syndrome affecting salivary glands, ${ }^{9}$ and focal myositis. Nevertheless, it remains unclear which factors lead to formation of LFLS in these diseases.

The lymphoid aggregates present in our muscle biopsies show a remarkable similarity to secondary lymphoid organs (SLOs) with distinct T- and B-cell compartmentalization. Expression of specific germinal center (GC) B-cell markers (BOB.1/Bcl-6) in the central B-cell-rich areas suggests a GC-like reaction in DM, similarly seen in true SLOs. It was previously reported that $\mathrm{jDM}$ patients with lymphoid follicle-like organization of the inflammatory infiltrate in muscle have a more severe and difficult-totreat disease. ${ }^{2}$ However, our patients, who slightly exceeded the age at onset of jDM, exhibited a rather mild clinical presentation and responded favorably to therapy. Brachio-cervical inflammatory myopathy, focal myositis, and "overlap syndrome" 8 were discussed as potential differential diagnoses and ruled out based on histologic, clinical, and ultrastructural (presence of undulating tubules) features. The outcome in patients with idiopathic inflammatory myopathy (IIM) has been studied recently. ${ }^{10}$ Most patients (68\%) with IIM (including DM) developed a polyphasic or chronic disease course. There were no significant differences between the different myositis subtypes with regard to disease course, mortality, and quality of life. ${ }^{10}$
Our observations illustrate the presence of LFLS in early adult-onset DM, which to our knowledge has not been reported yet. We show that the presence of LFLS is not necessarily evidence of an unfavorable prognosis in adult DM as opposed to reports in $\mathrm{jDM}$. In conclusion, this report enlarges the nosologic spectrum of DM.

\section{AUTHOR CONTRIBUTIONS}

Dr. Radke, Dr. Stenzel, and Dr. Goebel designed the study concept, did the analysis of data, participated in data acquisition, and drafted and revised the manuscript. Dr. Aronica, Dr. Pehl, Dr. de Visser, and Dr. Schonenberg-Meinema participated in the acquisition of data and drafted and revised the manuscript. Dr. Schneider participated in the acquisition of data. Dr. Heppner participated in revision of the manuscript.

\section{ACKNOWLEDGMENT}

The authors gratefully acknowledge excellent technical support by Petra Matylewski and Hanna Plückhan and thank Prof. Dr. M. Hummel for carrying out the B-cell clonality analysis.

\section{STUDY FUNDING}

No targeted funding reported.

\section{DISCLOSURE}

J. Radke has received travel funding from GlaxoSmithKline. D. Pehl has received research support from Deutsche Gesellschaft für Muskelkranke e.V. DGM. E. Aronica, D. Schonenberg-Meinema, and U. Schneider report no disclosures. F.L. Heppner is on the scientific advisory board for Baxter; holds a patent application for Modulators of IL-12 and/or IL-23 for the prevention or treatment of Alzheimer disease; is the founding scientist of Myosotis Therapeutics AG; and is a consultant for Sanofi and Novartis. M. de Visser is on the editorial board for Neuromuscular Disorders and Clinical Neurology and Neurosurgery. H.H. Goebel is on the editorial advisory boards for Neuromuscular Disorders, Muscle \& Nerve, Neuropathology and Applied Neurobiology, Brain Pathology, and Clinical Neuropathology. W. Stenzel is on the editorial board for Neuromuscular Disorders and Neuropathology and Applied Neurobiology. Go to Neurology. org/nn for full disclosures.

Received March 21, 2014. Accepted in final form June 26, 2014.

\section{REFERENCES}

1. Hoogendijk JE, Amato AA, Lecky BR, et al. 119th ENMC international workshop: trial design in adult idiopathic inflammatory myopathies, with the exception of inclusion body myositis, 10-12 October 2003, Naarden, The Netherlands. Neuromuscul Disord 2004; 14:337-345.

2. Lopez De Padilla CM, Vallejo AN, Lacomis D, McNallan K, Reed AM. Extranodal lymphoid microstructures in inflamed muscle and disease severity of new-onset juvenile dermatomyositis. Arthritis Rheum 2009;60: 1160-1172.

3. Preusse C, Goebel HH, Held J, et al. Immune-mediated necrotizing myopathy is characterized by a specific Th1-M1 polarized immune profile. Am J Pathol 2012;181: 2161-2171. 
4. De Visser M, Emslie-Smith AM, Engel AG. Early ultrastructural alterations in adult dermatomyositis. Capillary abnormalities precede other structural changes in muscle. J Neurol Sci 1989;94:181-192.

5. van Dongen JJ, Langerak AW, Bruggemann $M$, et al. Design and standardization of PCR primers and protocols for detection of clonal immunoglobulin and T-cell receptor gene recombinations in suspect lymphoproliferations: report of the BIOMED-2 Concerted Action BMH4CT98-3936. Leukemia 2003;17:2257-2317.

6. Jeffery GM, Golding PF, Mead GM. Non-Hodgkin's lymphoma arising in skeletal muscle. Ann Oncol 1991; 2:501-504.
7. Wedderburn LR, Varsani H, Li CK, et al. International consensus on a proposed score system for muscle biopsy evaluation in patients with juvenile dermatomyositis: a tool for potential use in clinical trials. Arthritis Rheum 2007;57:1192-1201.

8. De Bleecker JL, Engel AG, Butcher EC. Peripheral lymphoid tissue-like adhesion molecule expression in nodular infiltrates in inflammatory myopathies. Neuromuscul Disord 1996;6:255-260.

9. Aloisi F, Pujol-Borrell R. Lymphoid neogenesis in chronic inflammatory diseases. Nat Rev Immunol 2006;6:205-217.

10. van de Vlekkert J, Hoogendijk JE, de Visser M. Long-term follow-up of 62 patients with myositis. J Neurol 2014; 261:992-998. 


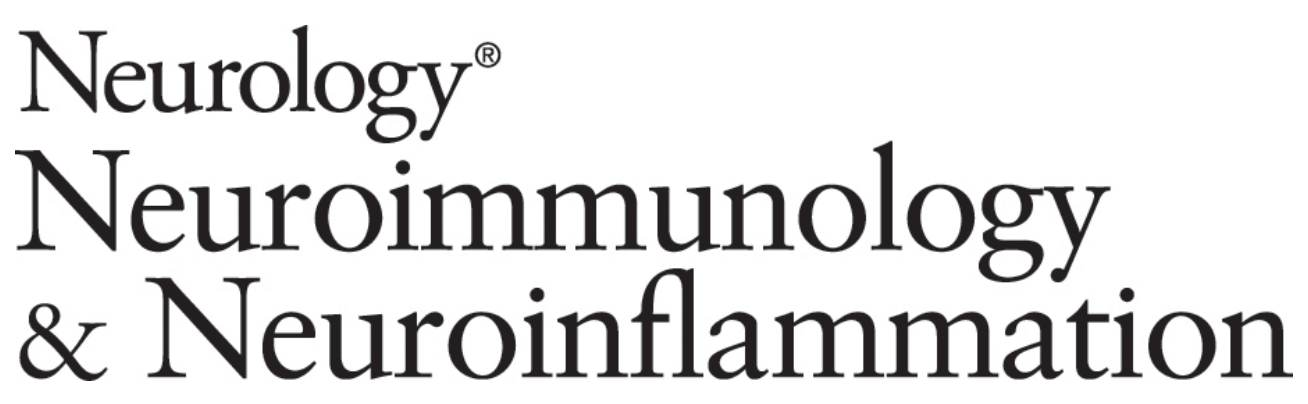

The lymphoid follicle variant of dermatomyositis Josefine Radke, Debora Pehl, Eleonora Aronica, et al.

Neurol Neuroimmunol Neuroinflamm 2014;1;

DOI 10.1212/NXI.0000000000000019

This information is current as of July 28, 2014

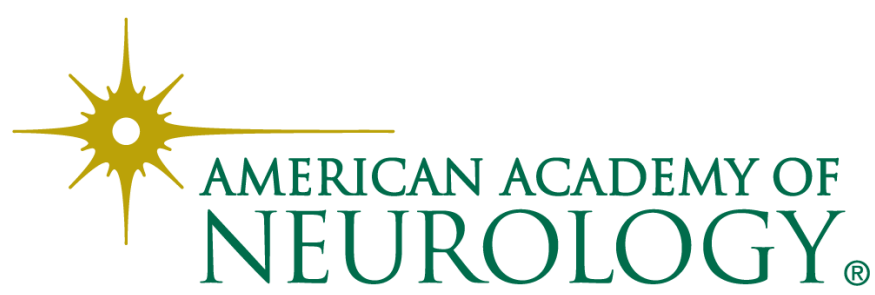




\section{Updated Information \& Services}

\section{Supplementary Material}

\section{References}

Citations

Subspecialty Collections

Permissions \& Licensing

Reprints including high resolution figures, can be found at: http://nn.neurology.org/content/1/2/e19.full.html

Supplementary material can be found at: http://nn.neurology.org/content/suppl/2014/07/28/1.2.e19.DC1

This article cites 10 articles, 0 of which you can access for free at: http://nn.neurology.org/content/1/2/e19.full.html\#\#ref-list-1

This article has been cited by 1 HighWire-hosted articles: http://nn.neurology.org/content/1/2/e19.full.html\#\#otherarticles

This article, along with others on similar topics, appears in the following collection(s):

\section{Adolescence}

http://nn.neurology.org//cgi/collection/adolescence

All Immunology

http://nn.neurology.org//cgi/collection/all_immunology

MRI

http://nn.neurology.org//cgi/collection/mri

Muscle disease

http://nn.neurology.org//cgi/collection/muscle_disease

Vasculitis

http://nn.neurology.org//cgi/collection/vasculitis

Information about reproducing this article in parts (figures,tables) or in its entirety can be found online at:

http://nn.neurology.org/misc/about.xhtml\#permissions

Information about ordering reprints can be found online:

http://nn.neurology.org/misc/addir.xhtml\#reprintsus

Neurol Neuroimmunol Neuroinflamm is an official journal of the American Academy of Neurology.

Published since April 2014, it is an open-access, online-only, continuous publication journal. Copyright $\odot$ 2014 American Academy of Neurology. All rights reserved. Online ISSN: 2332-7812.

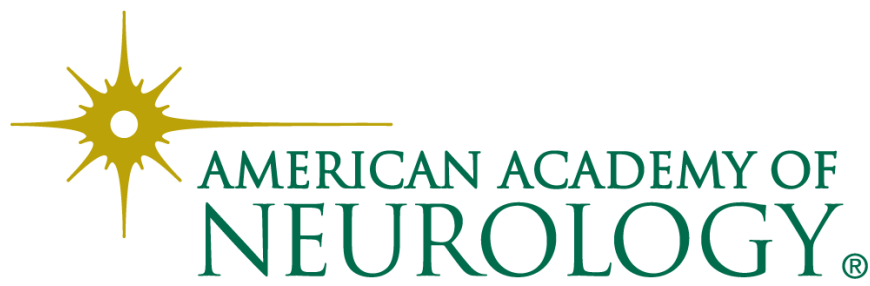

